American Journal of Pharmacology and Toxicology 2 (2): 65-74, 2007

ISSN 1557-619X

(C) 2007 Science Publications

\title{
Atomic Absorption Spectrometric Determination of Certain Fluoroquinolones in Pharmaceutical Dosage Forms and in Biological Fluids
}

\author{
${ }^{1}$ H. Salem, ${ }^{1}$ W. Khater and ${ }^{2}$ L. Fada \\ ${ }^{1}$ Analytical Chemistry Department, Faculty of Pharmacy, Minia University, Minia, Egypt \\ ${ }^{2}$ Biochemistry Department, Faculty of Pharmacy, Minia University, Minia, Egypt
}

\begin{abstract}
Simple, accurate, sensitive and selective methods are described for the quantitative determination of ten fluoroquinolones (amifloxacin, ciprofloxacin hydrochloride, difloxacin hydrochloride, enoxacin, enrofloxacin, lomefloxacin hydrochloride, levofloxacin, norfloxacin, ofloxacin and pefloxacin mesylate). The methods are based on precipitation of the ion associates formed from the reaction of the cited drugs with silver nitrate, copper acetate and ferric chloride. The formation and solubility of the solid complexes at the optimum conditions of $\mathrm{pH}$ and ionic strength values have been studied. The methods depend on direct determination of the ions in the precipitate or indirect determination of the ions in the filtrate by atomic absorption spectroscopy. The optimum conditions for precipitation were carefully studied. Rectilinear calibration graphs were obtained in the range of 10-100 ng. $\mathrm{ml}^{-1}$ for each of the investigated drugs and the limits of detection and quantitation ranged from 1.125 to $2.260,0.937$ to 2.754 and from 3.425 to $5.986 \mathrm{ng}^{-\mathrm{ml}^{-1}}$, respectively. The molar ratios of the formed chelats were determined by Job's method and their association constants were also calculated. The developed methods were applied successfully for the determination of the studied drugs in their pharmaceutical dosage forms with good precision and accuracy compared to official and reported methods as revealed by $t$-and $F$-tests. They were also applied for the determination of studied drugs in spiked urine and plasma samples.
\end{abstract}

Keywords: Fluoroquinolones; Atomic Absorption Spectrometry; Silver nitrate; copper acetate; Ferric Chloride; Pharmaceutical Dosage Forms; Biological Fluids.

\section{INTRODUCTION}

Quinolones comprise an interesting group of antibacterials whose action is based on their anti-DNA activity. They all possess a carboxylic group in position 3 , and a carbonyl group in position 4 , hence they are often referred to as 4-quinolones.

Their antibacterial activity is greatly increased by the addition of 6-fluoro and 7-piperazinyl groups to the molecule and named fluoroquinolones.

They are the second-generation members of quinolones and are greatly effective against both gram-negative and gram-positive pathogens that are resistant to other antibacterials ${ }^{[1]}$. The structures of the investigated quinolones are given in Table 1.

Several methods have been reported for the determination of quinolones in pure form, in dosage forms and in biological fluids. Nalidixic acid, norfloxacin, ciprofloxacin and its hydrochloride are official in both USP XXIV ${ }^{[2]}$ and BP $1998^{[3]}$, while ofloxacin is official in USP XXIV only. Both USP XXIV and BP 1998 recommend HPLC methods for determination of ciprofloxacin in raw material and in dosage forms. The USP XXIV recommends nonaqueous titration methods for determination of nalidixic acid, norfloxacin and ofloxacin in raw material, while HPLC methods are described for analysis of their dosage forms. The BP 1998 recommends a nonaqueous titration method for determination of nalidixic acid and norfloxacin in raw material and spectrophotometric method for determination of norfloxacin in dosage forms. Several methods for determination of quinolones including: titrimetric ${ }^{[4-6]}$, spectrophotometric [7-16], spectrofluorometric ${ }^{[17-24]}$, electrochemical [25-27], electrophoretic [28], and chromatographic methods ${ }^{[29-33]}$ were proposed. Several methods including chelation of fluoroquinolones with $\mathrm{Fe}(\mathrm{III})^{[8,13]}, \mathrm{Cu}(\mathrm{II})^{[18]}, \mathrm{Al}(\mathrm{III}){ }^{[16,19,22]}, \mathrm{Mg}$ (II) ${ }^{[16,19]}$, $\mathrm{Ca}$ (II) ${ }^{[16]}$ and $\mathrm{Tb}(\mathrm{III})^{[23]}$ were reported. Most of the analytical methods employed for the determination of

Corresponding Author: H. Salem, Department of Analytical Chemistry, Minia University, Minia, Egypt 
the studied drugs in biological fluids are HPLC methods which require complex and expensive equipment, provision for use and disposal of solvents, labour-intensive sample preparation procedure and personnel skilled in chromatographic techniques.

Although atomic absorption spectrometry is a rapid method and has very low detection limits which can not be reached by most of other methods, it has not been applied yet to the determination of these drugs. The present work includes new direct and indirect methods for determination of amifloxacin, ciprofloxacin hydrochloride, difloxacin hydrochloride, enoxacin, enrofloxacin, lomefloxacin hydrochloride, levofloxacin, norfloxacin, ofloxacin and pefloxacin mesylate. The present work represents the utilization of silver nitrate, copper sulphate and ferric chloride as reagents for the precipitation of the studied drugs followed by direct and indirect atomic absorption spectrometric measurements. The methods proved to be very sensitive and accurate for the determination of these drugs in bulk powders, in pharmaceutical dosage forms and in biological fluids.

\section{MATERIALS AND METHODS}

\section{Experimental}

Apparatus: Spectronic ${ }^{\mathrm{TM}}$ Genesys $^{\mathrm{TM}}$, UV/VIS spectrophotometer connected to an IBM computer loaded with the Winspec ${ }^{\mathrm{TM}}$ application software.

A Shimadzu atomic absorption flame spectrophotometer model AA.640-13. For AAS, silver, copper and iron were measured at wavelengths 240.7 , 298.3 and $316.2 \mathrm{~nm}$, respectively, slit width $0.2 \mathrm{~nm}$, relative noise 1.0 , detection limit $0.01 \mu \mathrm{g} / \mathrm{ml}$, lamp current $10 \mathrm{~mA}$ and integration time $3 \mathrm{~s}$. The flame used was the acetylene-air mixture.

The $\mathrm{pH}$ values of solutions were measured using an Orion Research Model 601A digital pH-meter. All calculations were carried out on IBM computer using Microsoft excel 2002 for windows ME. SMAC program ${ }^{[34]}$ was used for all statistical methods.

All solvents and reagents were of analytical reagent grade, double distilled water was used throughout. Samples of fluoroquinolones were generously supplied by their respective manufactures: amifloxacin (Sterling Winthrop Inc., USA); difloxacin hydrochloride (Abbott Laboratories, North Chicago, USA); norfloxacin (Eipico, Cairo, Egypt); ofloxacin (Hoechst AG, Frankfurt, Germany); ciprofloxacin hydrochloride (Miles Inc. Pharmaceutical Division,
West Haven, Germany); pefloxacin mesylate (RhonePoulenc Rorer, Neuilly/Seine, France); lomefloxacin hydrochloride (Searle, Illinois, USA); enoxacin, enrofloxacin and levofloxacin (Sigma Chem. Co., USA) and were used without further purification. silver nitrate, copper acetate and ferric chloride were Aldrich products.

Pharmaceutical preparations: The following available commercial preparations were analyzed: Spectrama $^{\circledR}$ tablets, Batch No. 814 (Amoun Pharmaceutical Industries Co., Cairo, Egypt) labeled to contain $400 \mathrm{mg}$ anhydrous norfloxacin per tablet; Neofloxacin ${ }^{\circledR}$ tablets, Batch No. 151 (Alexandria Co. for Pharmaceuticals, Alexandria, Egypt) labeled to contain $400 \mathrm{mg}$ anhydrous norfloxacin per tablet; Norbactin $^{\circledR}$ tablets, Batch No. 114 (Chem. Ind. Co., Giza, Egypt) labeled to contain $400 \mathrm{mg}$ norfloxacin per tablet; Tarivid ${ }^{\circledR}$ tablets, Batch No. 12E06 (Hoechst Orient, Cairo, Egypt, under license of Hoechst AG, Frankfurt, Germany) labeled to contain $200 \mathrm{mg}$ ofloxacin per tablet; Kirol $^{\circledR}$ tablets, Batch No. 021269A (Amoun Pharmaceutical Industries Co., Cairo, Egypt) labeled to contain $200 \mathrm{mg}$ ofloxacin per tablet; Mefoxin $^{\circledR}$ tablets, Batch No. 2011 (Misr Co. for Pharmaceutical Industries, Cairo, Egypt) labeled to contain $250 \mathrm{mg}$ ciprofloxacin hydrochloride monohydrate per tablet; Serviflox ${ }^{\circledR}$ tablets, Batch No. 950 (Under Licence from Biochemie Kundi Austria), labeled to contain 250 ciprofloxacin hydrochloride per tablet; $\quad$ Cipro $^{\circledR}$ otic drops, Batch No. 1001111 (Chem. Indus. Develop. Co.,Giza, Egypt) labeled to contain 3.5 mg ciprofloxacin hydrochloride per each $\mathrm{ml}$; Globacin $^{\circledR}$ tablets, Batch No. 18501 (Global Napi Pharm. Egypt) labeled to contain $400 \mathrm{mg}$ pefloxacin in the form of mesylate dihydrate per tablet; Peflacin $^{\circledR}$ ampoules, Batch No. 102 (Rhone-Poulenc Rorer, Neuilly/Seine, France) labeled to contain 400 $\mathrm{mg}$ pefloxacin mesylate dihydrate and $15.3 \mathrm{mg}$ sodium ascorbate per $5 \mathrm{ml}$ ampoule; Tavanic ${ }^{\circledR}$ tablets, Batch No. 12E07R (Under Licence of Aventis Pharma Germany) labeled to contain $500 \mathrm{mg}$ levofloxacin per tablet.

Standard preparations: Stock solutions containing 3 $\mu \mathrm{g} \mathrm{m} \mathrm{m}^{-1}$ of each fluoroquinolone were prepared in ethanol. Working standard solutions containing 100$1000 \mathrm{ng} \mathrm{ml}^{-1}$ were prepared by suitable dilution of the stock solutions with ethanol. 
Table 1: Structures of the investigated fluoroquinolones<smiles>[R]c1c(N2CCN([R3])C([R])C2)c(F)cc2c(=O)c(C(=O)O)cn([R])c12</smiles>

\begin{tabular}{|c|c|c|c|c|}
\hline Compound & $\mathrm{R}_{1}$ & $\mathrm{R}_{2}$ & $\mathrm{R}_{3}$ & $\mathrm{R}_{4}$ \\
\hline 1- Amifloxacin & $\mathrm{NHCH}_{3}$ & $\mathrm{H}$ & $\mathrm{CH}_{3}$ & $\mathrm{H}$ \\
\hline 2- Ciprofloxacin & & $\mathrm{H}$ & $\mathrm{H}$ & $\mathrm{H}$ \\
\hline 3- Difloxacin & $\mathrm{C}_{6} \mathrm{H}_{4}-\mathrm{F}$ & $\mathrm{H}$ & $\mathrm{CH}_{3}$ & $\mathrm{H}$ \\
\hline 4- Enoxacin & $\mathrm{C}_{2} \mathrm{H}_{5}$ & $\mathrm{H}$ & $\mathrm{H}$ & $\mathrm{H}$ \\
\hline 5- Enrofloxacin & & $\mathrm{H}$ & $\mathrm{C}_{2} \mathrm{H}_{5}$ & $\mathrm{H}$ \\
\hline 6- Lomefloxacin & $\mathrm{C}_{2} \mathrm{H}_{5}$ & $\mathrm{~F}$ & $\mathrm{H}$ & $\mathrm{CH}_{3}$ \\
\hline 7- Levofloxacin & & 1 & $\mathrm{CH}_{3}$ & $\mathrm{H}$ \\
\hline 8- Norfloxacin & $\mathrm{C}_{2} \mathrm{H}_{5}$ & $\mathrm{H}$ & $\mathrm{H}$ & $\mathrm{H}$ \\
\hline 9- Ofloxacin & & 1 & $\mathrm{CH}_{3}$ & $\mathrm{H}$ \\
\hline 10- Pefloxacin & $\mathrm{C}_{2} \mathrm{H}_{5}$ & $\mathrm{H}$ & $\mathrm{CH}_{3}$ & $\mathrm{H}$ \\
\hline
\end{tabular}

General procedure: Aliquots of working standard drug solutions were quantitatively transferred into $25 \mathrm{ml}$ measuring flasks. To each flask $1.0 \mathrm{ml}$ of $10^{-2} \mathrm{M}$ standard solution of silver nitrate, copper acetate and ferric chloride is added and $\mathrm{pH}$ was adjusted to 8.1 using $1 \mathrm{ml}$ of buffer solution. The solutions are shaken well and left to stand for $15 \mathrm{~min}$ and then filtered through Whatman $\mathrm{P} / \mathrm{S}$ filter paper $(12.5 \mathrm{~cm})$.

The precipitate was washed with redistilled deionized water until metal free.

Direct method: The precipitates obtained above were dissolved in the least amount of dilute acetic acid and complete to $25 \mathrm{ml}$ with redistilled deionized water. Two $\mathrm{ml}$ of the resulting solution was diluted to $25 \mathrm{ml}$ with redistilled deionized water.

Indirect method: The filtrates and washings were collected in $100 \mathrm{ml}$ volumetric flasks and completed to volume with redistilled deionized water. Ten $\mathrm{ml}$ of the resulting solution was diluted to $100 \mathrm{ml}$ with redistilled deionized water.
A blank (omitting addition of drugs) was prepared and absorbance was measured at the flaming conditions. Metal concentrations were calculated from calibration curves.

Procedure for tablets: An accurately weighed amount, equivalent to $10 \mathrm{mg}$ of each drug from composite of 20 powdered tablets, was transferred into a $100 \mathrm{ml}$ calibrated flask and diluted to the mark with redistilled de-ionized water, sonicated for $20 \mathrm{~min}$ and filtered off to obtain solutions of $100 \mu \mathrm{g} \mathrm{ml}^{-1}$. Further dilutions were made to obtain sample solution $\left(500 \mathrm{ng} \mathrm{ml}^{-1}\right)$, then the general procedure was followed.

Procedure for ampoules: A volume equivalent to 10 $\mathrm{mg}$ of each drug was transferred into 100 -ml calibrated flask and diluted to the mark with redistilled de-ionized water to obtain solution of $100 \mu \mathrm{g} \mathrm{ml}^{-1}$. Further dilutions were made to obtain sample solution (500 ng $\mathrm{ml}^{-1}$ ), then the general procedure was followed.

Procedure for drops: One milliliter of the drops was transferred into a $100 \mathrm{ml}$-calibrated flask and diluted to the mark with the appropriate solvent to obtain a solution of $30 \mu \mathrm{g} \mathrm{ml}^{-1}$. Further dilutions were made to obtain sample solution $\left(500 \mathrm{ng} \mathrm{ml}^{-1}\right)$, then the general procedure was followed.

Procedure for determination of molar ratio: Drug and metal solutions of equimolar concentrations $(1 \mathrm{x}$ $10^{-4} \mathrm{M}$ ) were prepared. Aliquots of each solution were added in different ratios to a series of $10 \mathrm{ml}$ calibrated flasks, so that the total volume of both is $5 \mathrm{ml}$.

The $\mathrm{pH}$ is adjusted to 8.1 using $1 \mathrm{ml}$ buffer solution and then the volume is completed with the appropriated solvent. The relative absorption intensity of each formed chelate is measured at its respective maxima.

Urine treatment: Urine samples were centrifuged at 4000 r.p.m. for $5 \mathrm{~min}$, then $1 \mathrm{ml}$ of the clear supernatant was spiked with $1 \mathrm{ml}$ of the drug stock solution.

Appropriate dilutions were made to obtain solutions in which the drug concentration is 100,300 and $500 \mathrm{ng}$ $\mathrm{ml}^{-1}$, then the general procedure was followed.

Plasma treatment: Five milliliter plasma were deproteinized by the addition of $10 \mathrm{ml}$ acetonitrile, centrifuged at 4000 r.p.m. for $5 \mathrm{~min}$. One milliliter of the clear supernatant was spiked with $1 \mathrm{ml}$ of the drug stock solution. The mixture was then extracted with 2 portions; each of $5 \mathrm{ml}$ chloroform. The chloroformic extract was collected, evaporated on a boiling water bath, then appropriate dilutions were made to obtain 
drug solutions containing 100, 300 and $500 \mathrm{ng} \mathrm{ml}^{-1}$, then general procedure was followed.

\section{RESULTS AND DISCUSSION}

Slightly alkaline ( $\mathrm{pH}$ 8.1) alcoholic solutions of amifloxacin, ciprofloxacin hydrochloride, difloxacin hydrochloride, enoxacin, enrofloxacin, lomefloxacin hydrochloride, levofloxacin, norfloxacin, ofloxacin and pefloxacin mesylate gave coagulated precipitates with silver nitrate, copper acetate or ferric chloride. These precipitates form the basis of the micro-quantitative determinations of the cited acidic drugs. $\mathrm{Ag}$ (I), $\mathrm{Cu}$ (II) or Fe (III) contents can be determined either directly in the precipitate or indirectly in the filtrate by atomic absorption spectrometry.

\section{Optimization of the reaction conditions}

Type and amount of alcohol: Addition of the recommended amount of ethyl alcohol is to enhance the solubilization of the drugs and coagulation of the precipitates. Larger volumes of alcohol must be avoided to prevent solubilization of the formed precipitates.

Effect of pH: In order to study the effect of $\mathrm{pH}$ on precipitation, buffer solutions covering the acid to alkaline range were tried. Acid media have a solubilizing effect on the precipitate leading to lower results for the direct technique and higher ones for the indirect technique while higher alkali media precipitate the metal as its oxide or hydroxide leading to higher results for the direct technique. The optimum $\mathrm{pH}$ was found to be slightly alkaline $(\mathrm{pH}=8.1)$.

Metal concentration: Considering metal ion concentration effect on precipitation, $1 \mathrm{ml}$ of the precipitating solutions was found to be sufficient for complete precipitation.

Temperature: Regarding the temperature effect on precipitation, room temperature was found to be the most efficient. Higher temperature show solubilizing effect on the precipitate producing lower results for the direct technique and higher ones for the indirect technique.

Composition of the formed complex: Job's method of continuous variation ${ }^{[35]}$ was used to study the molar ratios of the formed chelates. The method revealed 1:1, $1: 2$ and $1: 3$ ratios for the metal ions $(\mathrm{Ag}(\mathrm{I}), \mathrm{Cu}(\mathrm{II})$ and $\mathrm{Fe}(\mathrm{III})$, respectively): quinolone chelates (Figure 1).
This explains the use of the same optimum metal ion concentration for all the studied drugs.

The stability constants of the formed chelates were calculated using the following equations:

$$
\beta=\mathrm{A} / \mathrm{A}_{\mathrm{ex}} \mathrm{C}_{\mathrm{X}} /\left(\mathrm{C}_{\mathrm{M}}-\mathrm{A} / \mathrm{A}_{\mathrm{ex}} \mathrm{C}_{\mathrm{X}}\right)\left(\mathrm{C}_{\mathrm{L}}-\mathrm{nA} / \mathrm{A}_{\mathrm{ex}} \mathrm{C}_{\mathrm{X}}\right)^{\mathrm{n}}
$$

Where $\beta$ is the stability constant of the formed chelate, $\mathrm{M}$ indicates metal, $\mathrm{L}$ indicates ligand, $\mathrm{n}=\mathrm{X} /(1-\mathrm{X})$ where $\mathrm{X}$ is the mole fraction of the ligand at the maximum of the continuous variation curve. $\mathrm{A} / \mathrm{A}_{\mathrm{ex}}$ is the ratio of the observed absorbance to that indicated by the tangent for the same wavelength. $C_{M}$ and $C_{L}$ are the concentrations of the metal and the ligand, respectively, $\mathrm{C}_{\mathrm{x}}=\mathrm{C}_{\mathrm{L}} / \mathrm{n}=\mathrm{C}_{\mathrm{M}}{ }^{[36]}$.

The calculated stability constants for the formed chelates (Table 2) are ranging from $90.9093 \times 10^{7}$ to $198.0684 \times 10^{7}$ indicating good stability of the formed chelates.

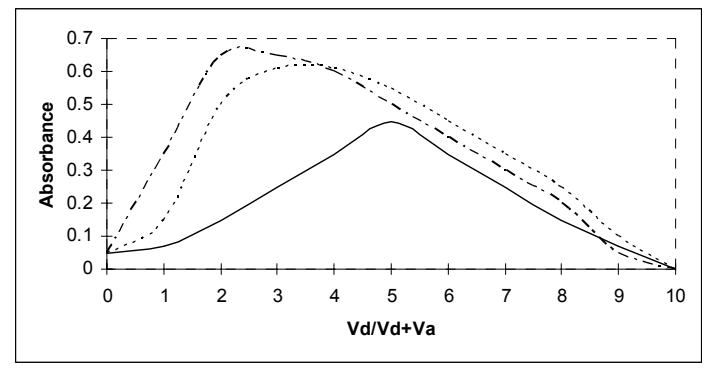

Fig.1: Job's curves of equimolar solutions of amifloxacin with silver (-), copper (- - - -) and iron (-..-.-..) at the respective maxima.

Method validation: The developed procedures were fully validated according to International Conference on Harmonization guidelines ${ }^{[37]}$ and complied with USP XXIV validation guidelines.

The methods were linear over the concentration ranges tested for the used metals. Calibration curves has correlation coefficients (r) higher than 0.999 and coefficients of determinations $\left(\mathrm{r}^{2}\right)$ higher than 0.998 (Table 3) indicating good linearity. Linearity was also checked by calculating the variance of the slope and $t$-test for the intercept (Table 3).

The accuracy of the methods were determined by investigating the recovery of each of the studied drugs at four concentration levels covering the specified range including $100 \%$ of the test concentration (three replicates of each concentration). 
Am. J. Pharm. \& Toxicol., 2 (2): 65-74, 2007

Table 2: Association constants of the formed chelates

\begin{tabular}{|c|c|c|c|c|c|c|}
\hline \multirow[t]{2}{*}{ Drug } & \multicolumn{2}{|l|}{ Sliver } & \multicolumn{2}{|l|}{ Copper } & \multicolumn{2}{|l|}{ Iron } \\
\hline & $\begin{array}{l}\text { Ass. Const. } \\
\mathrm{x} 10^{-7}(\mathrm{k})\end{array}$ & $\begin{array}{l}\log \\
(\mathrm{k})\end{array}$ & $\begin{array}{l}\text { Ass. Const. } \\
\mathrm{x} 10^{-7}(\mathrm{k})\end{array}$ & $\begin{array}{l}\log \\
(\mathrm{k})\end{array}$ & $\begin{array}{l}\text { Ass. Const } \\
\mathrm{x} 10^{-7}(\mathrm{k})\end{array}$ & $\begin{array}{l}\text { Log. } \\
(\mathrm{K})\end{array}$ \\
\hline Amifloxacin & 125.5894 & 8.9635 & 158.2658 & 9.0598 & 146.4356 & 9.5368 \\
\hline $\begin{array}{l}\text { Ciprofloxacin } \\
\text { Hydrochloride }\end{array}$ & 110.6514 & 9.0129 & 124.3684 & 8.4151 & 120.3112 & 9.2344 \\
\hline $\begin{array}{l}\text { Difloxacin } \\
\text { Hydrochloride }\end{array}$ & 142.6511 & 9.0265 & 112.3684 & 9.0651 & 142.2326 & 9.0932 \\
\hline Enoxacin & 135.824 & 8.9613 & 129.3895 & 9.062 & 153.7643 & 8.9753 \\
\hline Enrofloxacin & 157.6138 & 9.0589 & 109.1358 & 9.1868 & 126.8751 & 9.0032 \\
\hline $\begin{array}{l}\text { Lomefloxacin } \\
\text { Hydrochloride }\end{array}$ & 108.9865 & 9.1688 & 129.9812 & 9.1380 & 154.9542 & 9.1864 \\
\hline Levofloxacin & 90.9093 & 9.0019 & 126.9689 & 9.1811 & 114.9765 & 8.9998 \\
\hline Norfloxacin & 198.0684 & 9.1688 & 125.6947 & 9.0198 & 143.6433 & 9.8765 \\
\hline Ofloxacin & 106.9811 & 9.0029 & 142.6693 & 9.0886 & 167.9865 & 8.786 \\
\hline $\begin{array}{l}\text { Pefloxacin } \\
\text { Mesylate }\end{array}$ & 117.4493 & 9.2500 & 156.6552 & 9.0891 & 116.4353 & 9.1367 \\
\hline
\end{tabular}

*Average of three determinations

The results showed excellent recoveries (Table 4). The complete set of validation assays was performed for each drug with all of the studied metals. The limit of detection (LOD) and limit of quantitation (LOQ) were also determined (Table 3 ) according to the JCH guidelines ${ }^{[37]}$, the obtained values indicate the high sensitivity of the proposed methods.

The assay results were unaffected by the presence of excipients as shown by the excellent recoveries obtained when analyzing the studied drugs in presence of commonly encountered excipients (Table 5). Also, no interference was caused by the presence of sodium ascorbate with pefloxacin in the Pefloxacin ${ }^{\circledR}$ ampoules.

This fact indicates proper selectivity of the method for determination of the studied drugs in raw material and in their dosage forms. Different parameters affecting the procedures were studied to evaluate robustness; the analytical solutions were stable for at least $24 \mathrm{~h}$ showing reliability of the proposed methods.

Applications: The proposed procedures were applied successfully for determination of the studied drugs in their pharmaceutical dosage forms. Six replicate measurements were made in each case, the results obtained were validated by comparison with well established official and reported methods by means of $t$ and $F$-tests at $95 \%$ confidence level (Table 6), and no significant difference was detected indicating good accuracy and precision.

The high sensitivity attained by the proposed methods allows the determination of the studied quinolones in biological fluids. Therefore, the proposed methods were applied for determination of the studied drugs in spiked samples of human urine and plasma and the recoveries were determined by calibration curve method. Excellent recoveries were obtained at three concentration levels of each drug in both urine and plasma samples. The accuracy was assessed by investigating the recovery of each of the studied drugs at three concentration levels covering the specified range (three replicates of each concentration). The results showed excellent recoveries with S.D. less than $2.5 \%$ indicating both good accuracy and precision. Only plasma samples required deproteination and extraction steps while untreated urine samples are processed directly. This indicates that the proposed methods are selective enough to tolerate the presence of common excipients, other active constituents which may be found in different dosage forms (such as sodium ascorbate in Pefloxacin ${ }^{\circledR}$ ampoules) and matrices of biological fluids as urine and plasma. 
Am. J. Pharm. \& Toxicol., 2 (2): 65-74, 2007

Table 3: Parameters for calibration curves construction

\begin{tabular}{|c|c|c|c|c|c|c|c|c|c|}
\hline Drug & Procedure & $\begin{array}{l}\text { Conc. } \\
\text { range } \\
\left(\mathrm{ng} \mathrm{ml}^{-1}\right)\end{array}$ & $\mathrm{a}$ & $\mathrm{b}$ & $r$ & $\mathrm{r}^{2}$ & LOD & $\mathrm{LOQ}$ & $\begin{array}{l}\text { C.V. } \\
(\%)\end{array}$ \\
\hline \multirow[t]{6}{*}{ Amifloxacin } & Direct $^{I}$ & $10-60$ & -0.025 & 0.853 & 0.9996 & 0.9992 & 1.125 & 4.322 & 0.58 \\
\hline & Indirect $^{\mathrm{I}}$ & & 0.041 & 0.265 & 0.9995 & 0.9990 & 2.024 & 5.251 & 0.49 \\
\hline & Direct ${ }^{\mathrm{II}}$ & & 0.265 & 0.705 & 0.9997 & 0.9994 & 1.911 & 4.441 & 0.39 \\
\hline & Indirect ${ }^{\text {II }}$ & & -1.027 & 0.963 & 0.9996 & 0.9992 & 2.220 & 4.850 & 0.91 \\
\hline & Direct $^{\text {III }}$ & & 0.015 & 0.197 & 0.9997 & 0.9994 & 1.456 & 5.689 & 0.75 \\
\hline & Indirect ${ }^{\mathrm{III}}$ & & 0.107 & 0.657 & 0.9996 & 0.9992 & 1.467 & 4.356 & 0.64 \\
\hline Ciprofloxacin & Direct $^{\mathrm{I}}$ & $10-70$ & 0.599 & 0.801 & 0.9994 & 0.9988 & 2.114 & 3.950 & 0.37 \\
\hline \multirow[t]{5}{*}{ Hydrochloride } & Indirect ${ }^{\mathrm{I}}$ & & 1.200 & 0.710 & 0.9995 & 0.9990 & 2.098 & 4.871 & 0.58 \\
\hline & Direct ${ }^{I I}$ & & 0.911 & 0.521 & 0.9997 & 0.9994 & 2.211 & 4.747 & 0.80 \\
\hline & Indirect II & & 0.588 & 0.456 & 0.9996 & 0.9992 & 1.993 & 5.986 & 0.57 \\
\hline & Direct $^{\text {III }}$ & & 0.487 & 0.489 & 0.9997 & 0.9994 & 2.078 & 6.432 & 0.48 \\
\hline & Indirect $^{\mathrm{III}}$ & & 0.256 & 0.577 & 0.9999 & 0.9999 & 2.788 & 5.322 & 0.63 \\
\hline Difloxacin & Direct $^{I}$ & $10-80$ & 0.635 & 0.574 & 0.9994 & 0.9988 & 1.236 & 5.698 & 0.84 \\
\hline \multirow[t]{5}{*}{ Hydrochloride } & Indirect $^{\mathrm{I}}$ & & 0.666 & 0.158 & 0.9997 & 0.9994 & 2.124 & 4.901 & 0.49 \\
\hline & Direct $^{\text {II }}$ & & -0.058 & 0.207 & 0.9997 & 0.9994 & 1.952 & 4.499 & 0.51 \\
\hline & Indirect ${ }^{\mathrm{II}}$ & & 0.038 & 0.305 & 0.9997 & 0.9994 & 1.997 & 4.745 & 0.29 \\
\hline & Direct ${ }^{\text {III }}$ & & 0.063 & 0.428 & 0.9999 & 0.9999 & 2.086 & 5.362 & 0.56 \\
\hline & Indirect $^{\mathrm{III}}$ & & 0.021 & 0.457 & 0.9997 & 0.9994 & 2.743 & 5.899 & 0.64 \\
\hline \multirow[t]{6}{*}{ Enoxacin } & Direct $^{\mathrm{I}}$ & $10-80$ & -1.032 & 0.058 & 0.9995 & 0.9990 & 2.203 & 4.798 & 0.80 \\
\hline & Indirect ${ }^{I}$ & & 0.870 & 0.157 & 0.9996 & 0.9992 & 1.997 & 3.984 & 0.56 \\
\hline & Direct II & & 0.360 & 0.092 & 0.9996 & 0.9992 & 2.155 & 3.980 & 0.71 \\
\hline & Indirect ${ }^{\mathrm{II}}$ & & 1.201 & 0.795 & 0.9997 & 0.9994 & 2.201 & 4.379 & 0.55 \\
\hline & Direct ${ }^{\mathrm{III}}$ & & 0.056 & 0.578 & 0.9999 & 0.9999 & 1.456 & 5.477 & 0.89 \\
\hline & Indirect $^{\mathrm{III}}$ & & 0.024 & 0.367 & 0.9999 & 0.9999 & 1.854 & 4.876 & 0.76 \\
\hline \multirow[t]{6}{*}{ Enrofloxacin } & Direct $^{I}$ & $10-35$ & 0.957 & 0.741 & 0.9995 & 0.9990 & 1.908 & 3.981 & 0.81 \\
\hline & Indirect ${ }^{\mathrm{I}}$ & & 1.039 & 0.850 & 0.9996 & 0.9992 & 1.951 & 4.690 & 0.58 \\
\hline & Direct $^{\text {II }}$ & & -0.520 & 0.128 & 0.9998 & 0.9996 & 2.195 & 3.920 & 0.61 \\
\hline & Indirect ${ }^{\text {II }}$ & & 1.520 & 0.361 & 0.9998 & 0.9996 & 2.169 & 4.852 & 0.28 \\
\hline & Direct ${ }^{\text {III }}$ & & 0.147 & 0.287 & 0.9999 & 0.9999 & 1.864 & 5.367 & 0.45 \\
\hline & Indirect $^{\mathrm{III}}$ & & 0.175 & 0.467 & 0.9998 & 0.9996 & 1.365 & 4.797 & 0.67 \\
\hline Lomefloxacin & Direct $^{\mathrm{I}}$ & $10-60$ & 0.369 & 0.571 & 0.9995 & 0.9990 & 2.211 & 4.963 & 0.54 \\
\hline \multirow[t]{5}{*}{ Hydrochloride } & Indirect ${ }^{I}$ & & 0.661 & 0.548 & 0.9996 & 0.9992 & 2.069 & 4.987 & 0.61 \\
\hline & Direct ${ }^{\mathrm{II}}$ & & 0.368 & 0.471 & 0.9995 & 0.9990 & 2.101 & 4.802 & 0.67 \\
\hline & Indirect ${ }^{I}$ & & 0.995 & 0.985 & 0.9998 & 0.9996 & 1.992 & 4.556 & 0.58 \\
\hline & Direct ${ }^{\text {III }}$ & & 0.345 & 0.578 & 0.9999 & 0.9999 & 1.678 & 4.422 & 0.65 \\
\hline & Indirect ${ }^{\mathrm{III}}$ & & 0.432 & 0.321 & 0.9999 & 0.9999 & 2.087 & 5.895 & 0.43 \\
\hline \multirow[t]{6}{*}{ Levofloxacin } & Direct $^{\mathrm{I}}$ & $10-60$ & 1.254 & 0.399 & 0.9997 & 0.9994 & 1.921 & 5.691 & 0.49 \\
\hline & Indirect $^{\mathrm{I}}$ & & 0.369 & 0.250 & 0.9995 & 0.9990 & 2.120 & 4.631 & 0.51 \\
\hline & Direct $^{I I}$ & & -0.058 & 0.668 & 0.9996 & 0.9992 & 2.025 & 5.398 & 0.45 \\
\hline & Indirect ${ }^{\mathrm{II}}$ & & -0.998 & 0.269 & 0.9995 & 0.9990 & 2.260 & 5.490 & 0.90 \\
\hline & Direct ${ }^{\text {III }}$ & & 0.145 & 0.246 & 0.9999 & 0.9999 & 1.643 & 4.854 & 0.83 \\
\hline & Indirect $^{\mathrm{III}}$ & & 0.589 & 0.389 & 0.9999 & 0.9999 & 2.764 & 5.854 & 0.73 \\
\hline \multirow[t]{6}{*}{ Norfloxacin } & Direct $^{\mathrm{I}}$ & $20-100$ & 0.336 & 0.487 & 0.9997 & 0.9994 & 2.000 & 4.588 & 0.89 \\
\hline & Indirect ${ }^{\mathrm{I}}$ & & 0.998 & 0.069 & 0.9996 & 0.9992 & 1.996 & 5.597 & 0.80 \\
\hline & Direct $^{\mathrm{II}}$ & & 0.036 & 0.258 & 0.9997 & 0.9994 & 2.030 & 5.459 & 0.60 \\
\hline & Indirect ${ }^{\text {II }}$ & & 0.914 & 0.398 & 0.9995 & 0.9990 & 1.955 & 5.315 & 0.39 \\
\hline & Direct $^{\text {III }}$ & & 0.357 & 0.365 & 0.9999 & 0.9999 & 1.875 & 4.478 & 0.57 \\
\hline & Indirect ${ }^{\mathrm{III}}$ & & 0.269 & 0.789 & 0.9997 & 0.9994 & 1.755 & 4.367 & 0.68 \\
\hline \multirow[t]{6}{*}{ Ofloxacin } & Direct $^{I}$ & $10-60$ & -1.064 & 0.984 & 0.9997 & 0.9994 & 1.998 & 4.783 & 0.81 \\
\hline & Indirect $^{\mathrm{I}}$ & & 0.287 & 1.005 & 0.9995 & 0.9990 & 1.986 & 3.452 & 0.87 \\
\hline & Direct ${ }^{I I}$ & & 0.954 & 0.821 & 0.9996 & 0.9992 & 2.175 & 3.425 & 0.80 \\
\hline & Indirect $^{\text {II }}$ & & -0.985 & 0.871 & 0.9996 & 0.9992 & 2.125 & 4.851 & 0.49 \\
\hline & Direct $^{\text {III }}$ & & 0.578 & 0.579 & 0.9999 & 0.9999 & 1.643 & 3.754 & 0.73 \\
\hline & Indirect ${ }^{\mathrm{III}}$ & & 0.435 & 0.687 & 0.9999 & 0.9999 & 1.468 & 4.754 & 0.83 \\
\hline Pefloxacin & Direct $^{\mathrm{I}}$ & $10-80$ & 1.284 & 0.745 & 0.9995 & 0.9990 & 2.126 & 4.940 & 0.68 \\
\hline \multirow[t]{5}{*}{ Mesylate } & Indirect ${ }^{\mathrm{I}}$ & & 0.782 & 0.489 & 0.9996 & 0.9992 & 2.098 & 4.759 & 0.60 \\
\hline & Direct II & & 0.841 & 0.259 & 0.9998 & 0.9996 & 1.950 & 4.751 & 0.70 \\
\hline & Indirect ${ }^{\mathrm{II}}$ & & 0.561 & 0.486 & 0.9998 & 0.9996 & 2.049 & 4.763 & 0.81 \\
\hline & Direct $^{\text {III }}$ & & 0.769 & 0.568 & 0.9999 & 0.9999 & 1.352 & 4.854 & 0.95 \\
\hline & Indirect ${ }^{\mathrm{III}}$ & & 0.849 & 0.458 & 0.9999 & 0.9999 & 2.098 & 3.987 & 0.98 \\
\hline
\end{tabular}

a: intercept; b: slope; r: correlation coefficient; $\mathrm{r}^{2}$ : coefficient of determination; LOD: limit of detection; LOQ: limit of quantitation; Direct ${ }^{1}$ and Indirect ${ }^{1}:$ AAS using

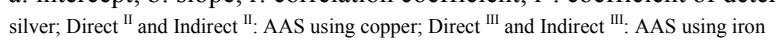


Am. J. Pharm. \& Toxicol., 2 (2): 65-74, 2007

Table 4: Statistical analysis of the results obtained using the proposed procedures and official or reported methods for analysis of authentic samples

\begin{tabular}{|c|c|c|c|c|c|c|c|c|}
\hline \multirow[t]{2}{*}{ Drug } & \multirow{2}{*}{\multicolumn{2}{|c|}{ Procedure }} & \multirow[b]{2}{*}{$\mathrm{X} \pm$ S.D. } & \multirow[b]{2}{*}{$\mathrm{V}$} & & & \multicolumn{2}{|c|}{ References method $^{\mathrm{a}}$} \\
\hline & & & & & $\mathrm{t}$ & $\mathrm{F}$ & $\mathrm{X} \pm$ S.D. & $\mathrm{V}$ \\
\hline \multirow[t]{6}{*}{ Amifloxacin } & \multirow[t]{2}{*}{$\mathrm{Ag}+$} & Direct & $100.6 \pm_{0} .50$ & 0.25 & 0.44 & 1.00 & \multirow[t]{6}{*}{$99.35 \pm 0.50$} & \multirow[t]{6}{*}{0.25} \\
\hline & & Indirect & $100.5 \pm 0.55$ & 0.30 & 0.52 & 1.20 & & \\
\hline & \multirow[t]{2}{*}{$\mathrm{Cu}^{2+}$} & Direct & $100.1 \pm 0.60$ & 0.36 & 0.06 & 1.44 & & \\
\hline & & Indirect & $99.7 \pm 0.49$ & 0.24 & 0.46 & 1.04 & & \\
\hline & \multirow[t]{2}{*}{$\mathrm{Fe}^{+3}$} & Direct & $98.4 \pm 0.83$ & 0.69 & 2.30 & 2.76 & & \\
\hline & & Indirect & $99.5 \pm 0.55$ & 0.30 & 0.85 & 1.21 & & \\
\hline Ciprofloxacin & \multirow[t]{2}{*}{$\mathrm{Ag}+$} & Direct & $99.5 \pm 0.60$ & 0.36 & 1.04 & 1.28 & \multirow[t]{6}{*}{$99.1 \pm 0.53$} & 0.28 \\
\hline \multirow[t]{5}{*}{ Hydrochloride } & & Indirect & $99.5 \pm 0.47$ & 0.21 & 0.48 & 1.33 & & \\
\hline & $\mathrm{Cu}^{2+}$ & Direct & $99.7 \pm 0.40$ & 0.16 & 0.27 & 1.75 & & \\
\hline & & Indirect & $99.8 \pm 0.55$ & 0.30 & 0.10 & 1.08 & & \\
\hline & $\mathrm{Fe}^{3+}$ & Direct & $99.5 \pm 0.50$ & 0.25 & 0.38 & 1.12 & & \\
\hline & & Indirect & $99.3 \pm 0.45$ & 0.20 & 0.77 & 1.40 & & \\
\hline Difloxacin & $\mathrm{Ag}^{+}$ & Direct & $99.5 \pm 0.55$ & 0.30 & 1.65 & 1.30 & $100.0 \pm 0.49$ & 0.23 \\
\hline Hydrochloride & & Indirect & $100.0 \pm 0.50$ & 0.25 & 0.00 & 1.09 & & \\
\hline & $\mathrm{Cu}^{2}$ & ${ }^{+}$Direct & $100.2 \pm 0.49$ & 0.24 & 0.16 & 1.04 & & \\
\hline & & Indirect & $98.2 \pm 0.55$ & 0.30 & 3.70 & 1.65 & & \\
\hline & $\mathrm{Fe}^{+3}$ & Direct & $99.7 \pm 0.55$ & 0.30 & 1.31 & 1.65 & & \\
\hline & & Indirect & $100.0 \pm 0.49$ & 0.24 & 0.63 & 1.04 & & \\
\hline Enoxacin & $\mathrm{Ag}^{+}$ & Direct & $99.5 \pm 0.48$ & 0.23 & 1.15 & 1.65 & $99.0 \pm 0.62$ & 0.38 \\
\hline & & Indirect & $99.2 \pm 0.50$ & 0.25 & 0.69 & 1.52 & & \\
\hline & $\mathrm{Cu}^{2+}$ & Direct & $99.8 \pm 0.74$ & 0.55 & 1.42 & 1.45 & & \\
\hline & & Indirect & $99.3 \pm 0.60$ & 0.36 & 0.28 & 1.05 & & \\
\hline & $\mathrm{Fe}^{3+}$ & Direct & $99.1 \pm 0.47$ & 0.21 & 0.72 & 1.81 & & \\
\hline & & Indirect & $99.8 \pm 0.49$ & 0.24 & 1.11 & 1.58 & & \\
\hline Enrofloxacin & $\mathrm{Ag}+$ & Direct & $100.2 \pm 0.74$ & 0.55 & 0.75 & 1.57 & $100.1 \pm 0.59$ & 0.35 \\
\hline & & Indirect & $99.3 \pm 0.54$ & 0.29 & 3.46 & 1.21 & & \\
\hline & $\mathrm{Cu}^{2+}$ & Direct & $100.4 \pm 0.66$ & 0.48 & 0.10 & 1.37 & & \\
\hline & & Indirect & $100.4 \pm 0.56$ & 0.31 & 0.03 & 1.13 & & \\
\hline & $\mathrm{Fe}^{3+}$ & Direct & $99.3 \pm 0.58$ & 0.34 & 4.50 & 1.03 & & \\
\hline & & Indirect & $101.0 \pm 0.83$ & 0.69 & 1.52 & 1.97 & & \\
\hline Lomefloxacin & $\mathrm{Ag}^{+}$ & Direct & $100.3 \pm 0.63$ & 0.39 & 0.20 & 1.63 & $100.1 \pm 0.49$ & 0.24 \\
\hline Hydrochloride & & Indirect & $99.8 \pm 0.82$ & 0.67 & 0.99 & 2.79 & & \\
\hline & $\mathrm{Cu}^{2+}$ & Direct & $98.8 \pm 0.70$ & 0.49 & 1.10 & 2.04 & & \\
\hline & & Indirect & $100.6 \pm 0.69$ & 0.48 & 0.30 & 2.00 & & \\
\hline & $\mathrm{Fe}^{3+}$ & Direct & $99.7 \pm 0.49$ & 0.24 & 0.91 & 1.00 & & \\
\hline & & Indirect & $100.4 \pm 0.66$ & 0.48 & 0.02 & 2.00 & & \\
\hline Levofloxacin & $\mathrm{Ag}^{+}$ & Direct & $100.1 \pm 0.70$ & 0.49 & 0.05 & 1.81 & $100.2 \pm 0.52$ & 0.27 \\
\hline & & Indirect & $1001.1 \pm 0.63$ & 0.39 & 0.04 & 1.44 & & \\
\hline & $\mathrm{Cu}^{2+}$ & Direct & $100.0 \pm 0.87$ & 0.77 & 0.03 & 2.85 & & \\
\hline & & Indirect & $100.0 \pm 0.59$ & 0.35 & 0.02 & 2.19 & & \\
\hline & $\mathrm{Fe}^{3+}$ & Direct & $99.8 \pm 0.66$ & 0.48 & 0.44 & 1.78 & & \\
\hline & & Indirect & $100.1 \pm 0.84$ & 0.71 & 0.05 & 2.63 & & \\
\hline Norfloxacin & $\mathrm{Ag}^{+}$ & Direct & $100.8 \pm 0.56$ & 0.31 & 0.23 & 1.30 & $100.1 \pm 0.49$ & 0.24 \\
\hline & & Indirect & $101.2 \pm 0.49$ & 0.24 & 0.89 & 1.00 & & \\
\hline & $\mathrm{Cu}^{2+}$ & Direct & $100.9 \pm 0.68$ & 0.46 & 0.43 & 1.92 & & \\
\hline & & Indirect & $100.0 \pm 0.78$ & 0.61 & 0.62 & 2.54 & & \\
\hline & $\mathrm{Fe}^{3+}$ & Direct & $100.7 \pm 0.39$ & 0.15 & 00.0 & 1.60 & & \\
\hline & & Indirect & $99.9 \pm 0.58$ & 0.34 & 1.82 & 1.42 & & \\
\hline Ofloxacin & $\mathrm{Ag}^{+}$ & Direct & $99.5 \pm 0.81$ & 0.66 & 0.68 & 1.65 & $99.3 \pm 0.63$ & 0.40 \\
\hline & & Indirect & $99.8 \pm 0.57$ & 0.32 & 1.08 & 1.25 & & \\
\hline & $\mathrm{Cu}^{2+}$ & Direct & $99.5 \pm 0.49$ & 0.24 & 2.02 & 1.67 & & \\
\hline & & Indirect & $99.9 \pm 0.77$ & 0.59 & 0.71 & 1.48 & & \\
\hline & $\mathrm{Fe}^{3+}$ & Direct & $99.1 \pm 0.68$ & 0.46 & 0.25 & 1.15 & & \\
\hline & & Indirect & $99.4 \pm 0.74$ & 0.55 & 1.92 & 1.38 & & \\
\hline Pefloxacin & $\mathrm{Ag}^{+}$ & Direct & $99.6 \pm 0.49$ & 0.24 & 0.18 & 1.50 & $99.9 \pm 0.40$ & 0.16 \\
\hline Mesylate & & Indirect & $99.8 \pm 0.57$ & 0.32 & 0.74 & 2.00 & & \\
\hline & $\mathrm{Cu}^{2+}$ & Direct & $99.5 \pm 0.70$ & 0.49 & 1.88 & 3.06 & & \\
\hline & & Indirect & $100.2 \pm 0.68$ & 0.46 & 1.39 & 2.88 & & \\
\hline & $\mathrm{Fe}^{3+}$ & Direct & $100.1 \pm 0.53$ & 0.28 & 1.42 & 1.75 & & \\
\hline & & Indirect & $100.0 \pm 048$ & 0.23 & 0.98 & 1.44 & & \\
\hline
\end{tabular}

Six and six determinations were used for the reported and the reference methods, respectively. The tabulated values of $\mathrm{t}$ and $\mathrm{F}$ at $95 \%$ confidence limit are $\mathrm{t}=3.58$ and $\mathrm{F}=4.28$. ${ }^{\mathrm{a}} \mathrm{Ref}$. 
Am. J. Pharm. \& Toxicol., 2 (2): 65-74, 2007

Table 5: Assay of the studied drugs in presence of common recipients

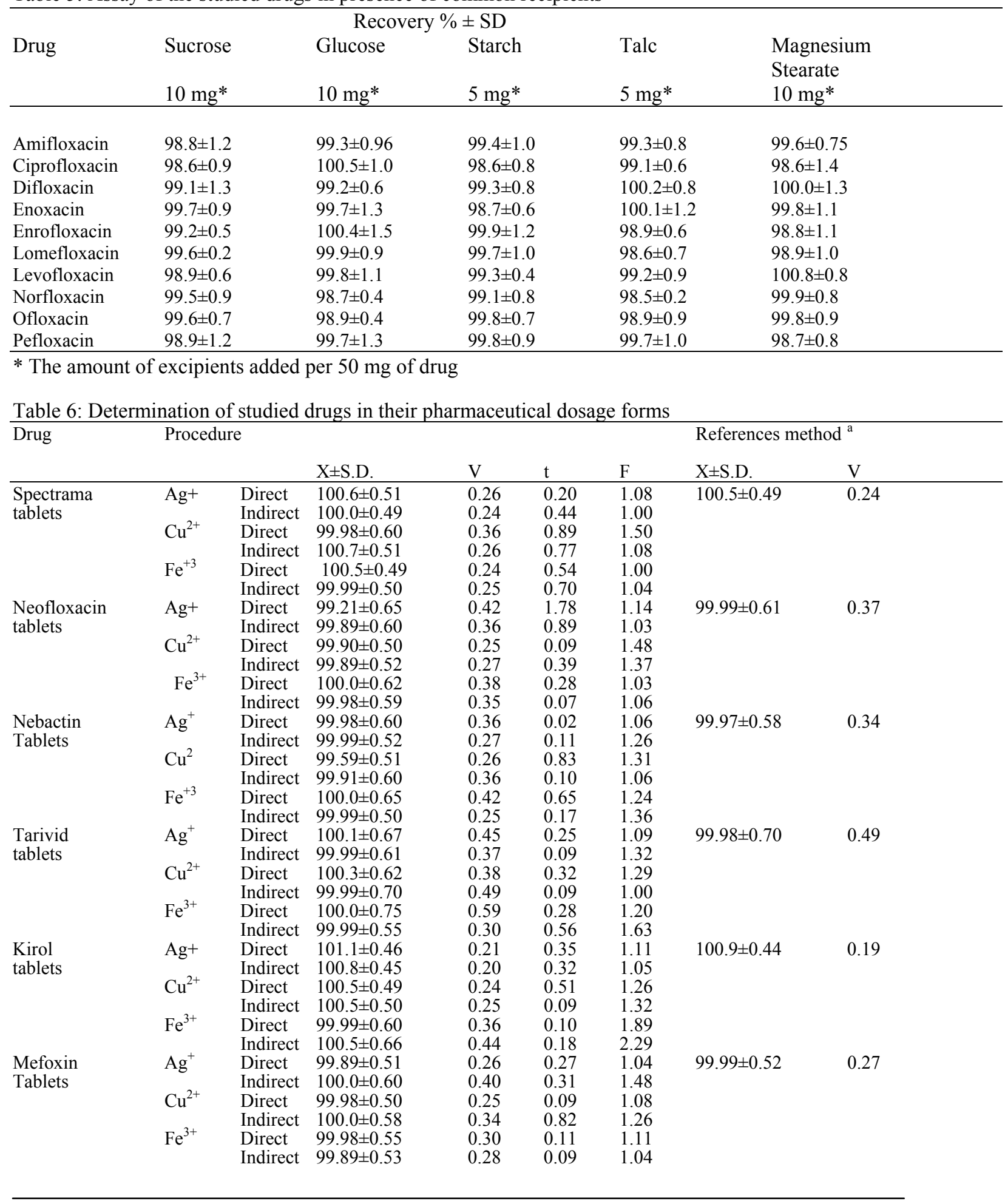


Am. J. Pharm. \& Toxicol., 2 (2): 65-74, 2007

Table 6 (Continuo): Determination of studied drugs in their pharmaceutical dosage forms

\begin{tabular}{|c|c|c|c|c|c|c|c|c|}
\hline \multirow[t]{2}{*}{ Drug } & \multirow{2}{*}{\multicolumn{2}{|c|}{ Procedure }} & \multirow[b]{2}{*}{$\mathrm{X} \pm$ S.D. } & \multirow[b]{2}{*}{$\mathrm{V}$} & \multirow[b]{2}{*}{$\mathrm{t}$} & \multicolumn{3}{|c|}{ References method ${ }^{\mathrm{a}}$} \\
\hline & & & & & & $\mathrm{F}$ & $\mathrm{X} \pm$ S.D. & $\mathrm{V}$ \\
\hline \multirow{6}{*}{$\begin{array}{l}\text { Serviflox } \\
\text { Tablets }\end{array}$} & \multirow[t]{2}{*}{$\mathrm{Ag}^{+}$} & Direct & $99.94 \pm 0.44$ & 0.19 & 0.14 & 1.37 & \multirow[t]{6}{*}{$99.99 \pm 0.51$} & \multirow{6}{*}{0.26} \\
\hline & & Indirect & $99.98 \pm 0.50$ & 0.25 & 0.09 & 1.04 & & \\
\hline & \multirow[t]{2}{*}{$\mathrm{Cu}^{2+}$} & Direct & $100.0 \pm 0.46$ & 0.21 & 0.34 & 1.24 & & \\
\hline & & Indirect & $99.98 \pm 0.44$ & 0.19 & 0.13 & 1.37 & & \\
\hline & \multirow[t]{2}{*}{$\mathrm{Fe}^{3+}$} & Direct & $99.92 \pm 0.63$ & 0.40 & 0.21 & 1.54 & & \\
\hline & & Indirect & $99.39 \pm 0.40$ & 0.20 & 0.84 & 1.30 & & \\
\hline \multirow{6}{*}{$\begin{array}{l}\text { Ciopro otic } \\
\text { drops }\end{array}$} & \multirow[t]{2}{*}{$\mathrm{Ag}^{+}$} & Direct & $100.0 \pm 0.49$ & 0.24 & 0.40 & 1.08 & \multirow[t]{6}{*}{$100.2 \pm 0.51$} & \multirow[t]{6}{*}{0.26} \\
\hline & & Indirect & $99.96 \pm 0.43$ & 0.18 & 1.27 & 1.44 & & \\
\hline & \multirow{2}{*}{$\mathrm{Cu}^{2+}$} & Direct & $100.1 \pm 0.53$ & 0.28 & 0.07 & 1.08 & & \\
\hline & & Indirect & $100.3 \pm 0.58$ & 0.34 & 0.93 & 1.31 & & \\
\hline & \multirow[t]{2}{*}{$\mathrm{Fe}^{3+}$} & Direct & $99.99 \pm 0.67$ & 0.45 & 1.20 & 1.73 & & \\
\hline & & Indirect & $100.4 \pm 0.54$ & 0.29 & 0.83 & 1.12 & & \\
\hline \multirow{6}{*}{$\begin{array}{l}\text { Glopactin } \\
\text { tablets }\end{array}$} & \multirow[t]{2}{*}{$\mathrm{Ag}^{+}$} & Direct & $98.85 \pm 0.40$ & 0.16 & 0.49 & 1.25 & \multirow[t]{6}{*}{$99.00 \pm 0.45$} & \multirow[t]{6}{*}{0.20} \\
\hline & & Indirect & $99.24 \pm 0.51$ & 0.26 & 0.89 & 1.30 & & \\
\hline & $\mathrm{Cu}^{2+}$ & Direct & $99.11 \pm 0.60$ & 0.36 & 0.53 & 1.80 & & \\
\hline & & Indirect & $99.48 \pm 0.63$ & 0.40 & 0.55 & 2.00 & & \\
\hline & \multirow[t]{2}{*}{$\mathrm{Fe}^{3+}$} & Direct & $99.21 \pm 0.54$ & 0.29 & 0.09 & 1.45 & & \\
\hline & & Indirect & $99.03 \pm 0.43$ & 0.18 & 0.45 & 1.11 & & \\
\hline \multirow{6}{*}{$\begin{array}{l}\text { Peflacin } \\
\text { Ampoules }\end{array}$} & \multirow[t]{2}{*}{$\mathrm{Ag}^{+}$} & Direct & $100.2 \pm 0.44$ & 0.19 & 0.60 & 1.11 & \multirow[t]{6}{*}{$100.0 \pm 0.46$} & \multirow[t]{6}{*}{0.21} \\
\hline & & Indirect & $100.4 \pm 0.51$ & 0.26 & 0.18 & 1.24 & & \\
\hline & $\mathrm{Cu}^{2+}$ & Direct & $100.2 \pm 0.40$ & 0.16 & 0.10 & 1.31 & & \\
\hline & \multirow{3}{*}{$\mathrm{Fe}^{3+}$} & Indirect & $100.1 \pm 0.51$ & 0.26 & 0.08 & 1.24 & & \\
\hline & & Direct & $99.99 \pm 0.58$ & 0.34 & 0.12 & 1.62 & & \\
\hline & & Indirect & $100.2 \pm 0.67$ & 0.45 & 0.17 & 2.14 & & \\
\hline
\end{tabular}

The proposed methods are advantageous than many of the reported spectrophotometric methods for determination of the studied drugs in pharmaceutical dosage forms and in biological fluids.

They are also much simpler and less expensive and time consuming than represented HPLC methods.

\section{CONCLUSION}

The proposed methods are simple, rapid, selective and highly sensitive. Therefore it is used for determination of the studied drugs either in bulk or in their corresponding dosage forms without interference from commonly used excipients. The high sensitivity of the methods also permits the determination of the studied drugs in biological fluids.

\section{REFERENCES}

1. Martindale, 2002. The Extra Pharmacopoeia, 33 rd. ed., Royal Pharmaceutical Society, London.

2. The United States Pharmacopoeia XXIV and NF XIX, 2000. American Pharmaceutical Association, DC.

3. The British Pharmacopoeia 1998. H.M. Stationary Office, London.
4. Tuncel M. and Z. Atkosar, 1992. Titrimetric analysis of certain fluoroquinolones: Pharmazie, 47: 642.

5. Baraza C. and A. Korolkovas, 1985. Rev. Farm. Bioquim. Univ. Sao Paulo, Analytical study of certain quinolones. 21: 141

6. Kilic E., F. Koseoglu and M. A. Akay, 1994. Nonaqueous titration of some quinolones: J. Pharm. Biomed. Anal., 12: 347

7. Kapetanovic V., L. Milovanovic and M. Ereeg, 2001. Spectrophotomeric determination of sixth fluoroquinolones. Talanta, 43: 2123.

8. Sultan S. M. and F. O. Suliman, 1993. Analytical study of quinolones. Analyst 118: 573.

9. Elkhateeb S. Z., S. A. Abdelrazek and M. M. Amer, 1998. Spectrophotometric determination of certain quinolones. J. Pharm. Biomed. Anal. 17: 829.

10. Fratini L., E. and S. Schapoval, 1996. Utility of CTC for determination of certain antibiotics. Int. J. Pharm. 12: 279.

11. Elwalily A. F. M., A. Razak, S. F. and Belal, R. S. Bakry, 1999. Colorimetric analysis of quinolones. J. Pharm. Biomed. Anal. 21: 1069

12. Mostafa, S., M. El-Sadek and.E. Awadalla, 2002. Spectrophotometric determination of ciprofloxacin, enrofloxacin and pefloxacin through charge transfer complex formation. J. Pharm. Biomed. Anal., 27: 133-142 
13. Zhao, F.L., B.Z. Xu, Z.Q. Zhang and S.Y. Tong, 1999. Analysis of certain fluoroquinolones by charge transfer reactions. J. Pharm. Biomed. Anal., 21: 355

14. Patel H.; Fursule, R. A. and Talele, G. S. 2005. Spectrophotometric method for the determination of lomefloxacin hydrochloride. Indian Pharm., 4(40): 67-68.

15. Salem, H., 2004. Colorimetric and atomic absorption spectrometric determination of some fluoroquinolone derivatives. Sci. Pharm., 72: 5171.

16. Salem, H., 2005. Spectrofluorimetric, atomic absorption spectrometric and spectrophotometric determination of some fluoroquinolones. Am. J. Appl Sci., 2: 719-729.

17. Espinosa M. A.; Munoz P. A.; Canada, F. and Gonzalez G. D. 2005. Determinations of fluoroquinolones in urine by extractive spectrophotometry and photoinduced spectrofluorimetry using multivariate calibration. Anal. Biochem. 347(2): 275-286

18. Vilchez, J.L., O. Ballesteros, J. Taoufiki, G.S. Palencia and A. Navalon, 2001. A novel spectrofluorimetric method for determination of lomefloxacin based on supramolecular inclusion complex between it and $\mathrm{p}$-sulfonated calyx ${ }^{[4]}$ arene. Anal. Chim. Acta, 444: 279.

19. Veiopoulou, C.J., P.C. Lounici and E.S. Lianidou, 1997. Fluorimetric analysis of certain fluoroquinolones. J. Pharm. Biomed. Anal., 15: 1839.

20. Stankov M. J., D. Stankov and P. Djurdjevic, 1999. Fluorometric analysis of certain fluoroquinolones. Pharmazie 5: 73 .

21. Artesros A. H., R. Compano and M. D. Prat, 1998. Analysis of certain quinolones in biological fluids. Analyst 123: 609.

22. Perez-Ruiz T., C. Martinez-Lozano, V. Tomas and J. Carpena, 1997. Fluorometric determination of some drugs. Analyst 122: 705.

23. Tieli Z., Z. Huishun and J. Linpei, 1999. Utility of certain regents for fluorometric analysis of fluoroquinolones. Talanta 4:, 129.

24. Wu S., W. Zhang, X. Chen, Z. Hu, M. Hooper, B. Hooper and Z. Zhao; 2001. Fluorometric analysis of certain fluoroquinolones in biological fluids. Spectrochim Acta A Mol. Biomol. Spectrpsc. 57(6): 1317
25. Jaber, A.M.Y. and A. Lounici, 1994. Polarographic analysis of certain fluoroquinolones. Anal. Chim. Acta, 291: 53

26. Rizk, M., F. Belal, F. Ibrahim, S. Ahmed and N. El-Enany, 2000. Spectrofluorimetric analysis of certain 4-quinolone in pharmaceuticals and biological fluids. J. Pharm. Biomed. Anal., 24: 21.

27. Christian, H. and B. Gottfried, 2001. Development of capillary electrophoresis methods for the analysis of fluoroquinolones and application to the study of the influence of humic substances on their photodegradation in aqueous phase. J. Chromatogr. B, 754: 168-178.

28. Fierens C., S. Hillaert and W. Vanden Bossche, 2000. Analysis of certain fluoroquinolones. J. Pharm. Biomed. Anal. 22: 763.

29. Novakovic J., K. Nesmark, H. Nova and K. Filka, 2001. HPLC analysis of certain fluoroquinolones. J. Pharm. Biomed. Anal., 25: 957.

30. Walker S. T., 1996. Chromatograohic study of some drugs. J. AOAC 79: 431

31. Gigosos P. G., P. R. Revesado, O. Cadahia, C. A. Fente, B. I. Vazquez, C. M. Franco and A. Cepeda,2000. Chromatographic analysis of certain fluoroquinolones. J. Chromatogr. A 87 (1-2): 31

32. Samanidou V. F., C. E.. Demetrious and I. N. Papadoyannis, 2003. Validity of chromatographic methods for determination of fluoroquinolones. Anal. Bioanal. Chem. 375 (5): 623.

33. Marazuela M. D. and M. C. Moreno-Bondi, 2004. High performance liquid chromatographic methods for determination of fluoroquinolones. J. Chromatogr. A 1034 (1-2): 25.

34. Meiere P. C. , R. E. Zund and J. Wiley, 1993. Statistical Methods In Analytical Chemistry $\left(\mathrm{SMAC}^{\circledR}\right)$.

35. Foster, R., 1969. Organic Charge-transfer Complexes.Academic Press, London, pp: 623-755

36. Sawyer D. T., W. R. Heinman and J. M. Beebe, 1984. Chemistry Experiments for Instrumental Methods, Wiley, New York ,pp. 205.

37. Topic Q2B. 1996. Validation of Analytical Procedures: Methodology, International Conference on Harmonisation (ICH). 